\title{
Social Media Marketing Effects On Corporate Social Responsibility
}

Christina B. Curley, Salve Regina University, USA

Nadia Abgrab Noormohamed, Salve Regina University, USA

\begin{abstract}
Today's customers are marketing representatives, product designers, intimate and privileged 'friends' of the company, and de facto managers sitting in at a corporate retreat; they are major stakeholders who bring the concept of corporate social responsibility to the forefront. Since sustainability, connection with community and serving society are expectations consumers require from companies from which they buy, work, and invest; companies must continually look for innovative methods to communicate their alignment of socially responsible policies into their strategic plan. While such concepts are rooted in a collaborative mission, social media marketing is a natural platform for cultivating and instilling such corporate messages.
\end{abstract}

Keywords: Social Media Marketing; Corporate Social Responsibility; CSR

\section{SOCIAL MEDIA MARKETING PLATFORM}

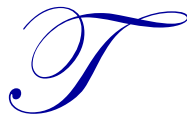

here is much hype about social network platforms and their potential impact on global marketing; therefore many companies are diligently establishing a presence on Facebook, Twitter (one key benefit is it allows for casual communication with customers on their terms, resulting in affable relationships, which is difficult for companies to achieve in other media [Skill Path Seminars]); and other platforms such as Pinterest, Foursquare, Tumblr, Instagram, and Blogs to build brand awareness and develop customer engagement. Social media marketing is becoming a richer vehicle to allow corporations to interact with various customers, who increasingly view themselves as "active co-creators" of corporate programs, rather than as mere "passive recipients" of corporate messaging.

Consumers believe the way one chooses to engage with companies has real consequences for the world. According to Dolliver, social media marketing can be used to get constituents involved, "ways to volunteer, to sign a petition, to spread the word, to really become advocates for the cause... It can help consumers track the impact of a company's involvement with a cause... It can add that human and emotional component." It requires two-way communication by asking and answering questions through social media pages and multiple media devices to pique the interests of potential consumers or to maintain that connection with those who are loyal patrons. As stated by McKinsey in his Quarterly Report, "Expressing consumer behavior as a winding journey with multiple feedback loops, this new framework was different from the traditional description of consumer purchasing behavior as a linear march through a funnel. Social media is a unique component of the consumer decision journey; it's the only form of marketing that can touch consumers at each and every stage, from when they're pondering brands and products right through the period after a purchase, as their experience influences the brands they prefer and their potential advocacy influences others" (2012).

Escalated over the years and infiltrated into mainstream opinion, this social movement has put pressure on corporations to develop and to harness their content marketing to creatively attract the intended audience. A consumer, as defined by Dictionary.com, is a person who purchases goods or services from another. While said definition may have been inclusive 20 years ago, in a world driven by 'deep data' deluge whether customer, interaction, and/or social data, opportunities to increase sales productivity and effective brand management through levering digital (web, mobile, social, email) channels should not be missed (Beneyre, 2012). Emphasizing mobile adoption and usage rates, opens the door for marketers to reach targeted audiences in a variety of new ways, 
including branded apps, online coupons, quick response $(\mathrm{QR})$ codes, text messages, advertising, location-based services, and mobile websites (Colan, 2011). This interconnectivity provides a great opportunity for businesses of all sizes to embrace this movement and adopt advocacy tools, techniques, people, and processes into their communication messages; not only for a person-to-person reach, but also for a machine-to-machine connection (Bateman, 2013).

Involvement with the customer is a constant challenge of interacting with that target audience. One way to build brand awareness and loyal advocates is to keep them involved and to deploy a fun, creative way for supporters to participate in and to share with online friends (Hall, 2011). Allowing your 'friends' to promote your business through recommendations and interesting relationships secures that competitive edge in the marketplace. As the adage goes, "there's power in numbers" and social media provides companies - who actively engage - with an influential, built-in network of passionate consumers who become followers of a brand when interested in what it is doing. In the United States, e-commerce sales alone for 2013 are estimated to be $\$ 259$ billion, a 14.8 percent annual increase (eMarketer); interestingly 92 percent of purchases take place offline - following online consumer activity as reported by Forrester Research, Yahoo, and comScore (Zalk, 2013).

\section{CORPORATE SOCIAL RESPONSIBILITY}

Corporate social responsibility (CSR) is a trend in corporate policy which serves as a self-regulatory guide to socially and environmentally responsible business practices. This expansion of long held principles of business ethics generally centers in balancing profit requirements of shareholders with elements of social responsibility. Since real-time predictive insights will provide that competitive edge, executives must first collect data to identify patterns and be prepared to lead the charge to transform the purchasing power of the present day customer, by knowing where and how to spend the marketing dollars in a personalized acquisition campaign (Bateman, 2013). As stated by Marsha Collier, author of several books on social media customer service, in an interview for NBC News, "You have to know customer service, but you also have to understand marketing, understand corporate communication, human resources - you have to understand all these components" (2013).

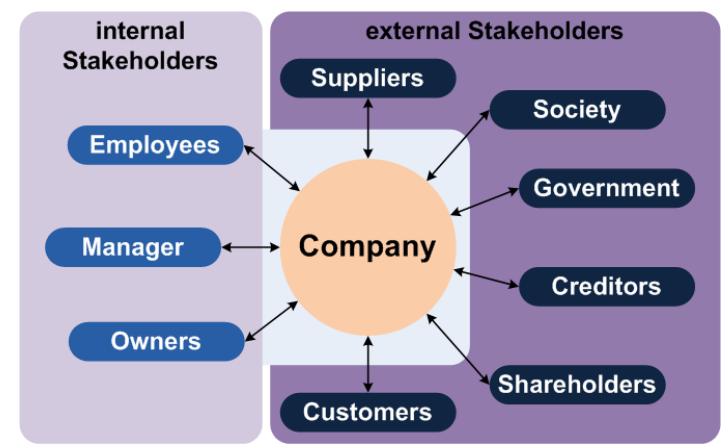

Figure 1: Various Types of Stakeholders

Source: http://www.ehow.com/info_8175777_consumer-stakeholder.html\#ixzz2YZN9bfBu

Branco and Rodrigues (2007) describe the stakeholder perspective of CSR as the inclusion of all groups or constituents (rather than just shareholders) in managerial decision making related to the organization's portfolio of socially responsible activities. This normative model implies the CSR collaborations are positively accepted when they are in the interests of stakeholders' insights, and may have no effect or may be detrimental to the organization if they are not directly related to stakeholder interests. Stakeholder theory claims firms can change their social behavior in response to such pressure of salient stakeholder groups, while also understanding the needs of the business.

Many companies are now embracing the CSR concept with a vengeance. According to Bhattacherya, companies are reengineering supply chains to make them become 'greener,' supporting social causes through volunteer programs for employees or lobbying for human rights in remote corners of the globe. In practical terms, this involves moving away from a top-down strategy determined by a board-of-directors, to a richer process of 
bottom-up co-creation with stakeholders. It means using focus group data and other marketing research techniques to understand the deeper psychological behavioral needs answered for stakeholders, such as the self-esteem and lifetime value of the consumer.

Even though there is clearly a greater push for CSR, the challenge is to map out and to deliver the message in many sectors in a timely manner. As repeated by Dolliver (2011) only 11 percent of respondents answered affirmatively when asked whether they had encountered communications from any company in the past year about CSR. In Cone's polling, 61 percent of respondents said they do not think companies are "giving them enough details about their efforts" and 73 percent of those polled by the Hartman Group agreed that, "I would like to see companies' sustainable practices be more visible to the public" to drive traffic to their websites. According to The CMO Survey, responses from 468 top marketers in February 2013, companies are spending 8.4 percent of their budgets on social media with an expected increase to 24.6 percent in the next five years by companies such as Procter \& Gamble and The Coca-Cola Company (Moorman, 2013).

\section{IMPORTANCE OF SOCIAL MEDIA MARKETING TO CORPORATE SOCIAL RESPONSIBILITY MISSION}

There are many opportunities and challenges today for consumers' behavior to impact corporate trustworthiness and commitment on social issues. It can range from a groundswell of local organizations and communities to the 'Yes Men's' parity of movies and social media impact on corporate greed. The 'Yes Man' used social media to release a fake press release for a Chevron ad campaign that included a commitment and reference to a years-long lawsuit in Ecuador, where Chevron is accused of being responsible for $\$ 27$ billion of oil pollution clean-up costs (Zax, 2010). Major magazines and network outlets were duped by the hoax and had to retract statements made by the initial release. The URL was so close to the actual company web address that it was missed by many. This was a testament to the contagious speed of viral marketing and value of social network outlets to bring the latest news to millions of people in the shortest time possible with more impact and less cost than conventional forms of promotion.

Social media can be helpful in connecting consumers and companies around a cause to emphasize social responsibility. Alison DaSilva, executive VP at Cone, a leading public relations and marketing firm in corporate social responsibility and cause marketing, said social media gives companies "multiple touchpoints" for engaging consumers. A powerful example of how companies are learning ways in which to use social media is in the realworld case of Procter \& Gamble who developed a program for Facebook called, "The Future Friendly Challenge" to help consumers save energy, conserve water, and reduce waste for Children's Safe Drinking Water. Through this simple Facebook strategy, the online initiative generated strong return-on-engagement data in just a few months with more than 20,000 followers who have taken the challenge and committed to saving energy, water, or reducing waste for 90 days - translating to over 20,000 days of clean drinking water donated. More than 7,000 posts have been made by supports with their tips and experiences on how to save energy, conserve water, and reduce waste (Baer, 2010). Such social media communities exist in numerous arenas to cross-sell mutual interests and exchange shared values.

Corporate responsibility acts as a conduit through which companies can demonstrate their concern about stakeholders, as defined in Figure 1. According to Dolliver, "whatever the focus of a company's socialresponsibility program, it needs to be a sustained effort rather than a transitory drive-by. We need to find compelling new ways to help consumers cut through the marketing fog." Whole Foods market, the industry leader in organic and natural foods, has a very active website that takes their customers from health and wellness to the CEO's blog, exclusively through the use of Twitter. Responses to customer comments make up 85 percent of all the tweets sent, 10 percent of the tweets are content-based and 5 percent are promotional (Stanchak, 2010). Much of Whole Foods message is about sustainability, healthier lifestyles, fair trade, supporting local agriculture, and businesses as suppliers. This coupled with a strong role in generating frequent awareness of corporate social responsibility will solidify the relationship and ultimately create value.

CVS/Caremark, the largest pharmacy health care provider in the United States, has focused their CSR using a unique set of assets to reinvent pharmacies and to create sustainable solutions involving many of their key internal 
and external stakeholders. As outlined in their 6th annual report emphasizing CSR, their mission is to empower stakeholders with time sensitive analytics to enhance access to care, to provide outreach initiatives, and to educate particular interest groups - all in an effort to contribute to lower health care costs for customers and payors (government and health care providers). Incorporating various segmentation factors, CVS/Caremark partnered with Enroll America (a nonpartisan nonprofit organization) and The Medicine Abuse Project (an initiative of The Partnership at Drugfree.org, which aims to prevent a half-million teens from abusing medicine) to ensure patients are well-advised and act responsibly on prescription and health care options.(CVS, 2013).

Social media has risen in the ranks of inclusion in many core business strategies and is quickly becoming a key component within the marketing value equation. UnitedHealth has implemented a dashboard to customers and other public audiences to demonstrate the company's commitments toward social progress. Their social responsibility dashboard allows for the measure of attribute characteristics and includes metrics for workplace engagement, ethics, and integrity; supplier diversity; environmental impact; employee-community involvement; stakeholders' perspectives on social responsibility; and community giving (Bonini, 2009) by increasing brand awareness at minimal expense.

To further gain supporters, Hall (2010) believes in the straightforward transparent social media approach to harness and highlight a company's long-term commitment to corporate social responsibility. This spirit of sharing good news she believes will help to spread the word, amplify their cause(s), and galvanize a powerful network of friends. Showcasing the strides a company made for the cause (whether this means funds donated, awareness raised, consumers reached, beneficiaries helped, communities improved, etc.), Target@ created a local solution to a national issue by personally connecting with parents through a timely and innovative social media campaign. While demonstrating the company's social responsibility and commitment to schools and education, they partnered with Search Institute ${ }^{\circ}$ to develop and to implement the 'Turn Summer Play into Summer Learning' series on its Facebook page providing savvy parents with fun, weekly tips to help their child's mind stay active during the summer with research on how it makes a positive impact on child development.

\section{CONCLUSION}

Creating buzz and excitement, social media marketing can impact corporate social responsibility (CSR) in numerous ways both internally and externally. By keeping dialogues open with customers, suppliers, and investors; companies develop a further understanding and confidence in the commitment to the concept of social responsibility. Leveraging CSR in the social media world can strengthen consumer trust and loyalty, encourage followers (and their friends) to take action and participate, and put a halo over the brand that dives in (Baer, 2010). A change in the social media landscape offers a tremendous opportunity for companies to integrate new media options into their marketing strategy, creating a balance of power with consumers, media, and other parties to drive meaningful business outcomes and dramatically and expedientially improve the performance of their marketing programs.

\section{AUTHOR INFORMATION}

Christina B. Curley, Ph.D., Salve Regina University, Marketing Department, 100 Ochre Point Avenue, Newport, RI 02840-4192, USA.

Nadia Abgrab Noormohamed, Ph.D., Salve Regina University, Marketing Department, 100 Ochre Point Avenue, Newport, RI 02840-4192, USA. E-mail: nadia.abgrab@salve.edu (Corresponding author)

\section{REFERENCES}

1. Baer, J. (2010, July 6). Tying together social media and corporate social responsibility. Retrieved from http://socialmediatoday.com/jasonbaer/142850/tying-together-social-media-and-corporate-socialresponsibility 
2. Bateman, M. (2013, July 24). A marketer's guide to customer analytics: People, processes \& technology. Marketing Manager IBM. Retrieved from https://owa.salve.edu/owa/redir.aspx?C=9ca43c330a8c44bd92fb7d9e9ecb1b94\&URL=https\%3a\%2f\%2fev ent.on $24 . c o m \% 2$ finterface $\% 2$ fregistration $\% 2$ fautoreg $\% 2$ findex.html $\% 3$ feventid $\% 3 \mathrm{~d} 623043 \% 26$ sessionid \%3d1\%26key\%3dE8A792A9103A24798D5D8CB71E46B9A6\%26partnerref\%3dKF-PI

3. Beneyre. (2012, May 9). Using social media to engage with stakeholders. Retrieved from http://panopticonpolicy.com/author/beneyre

4. Bhattacharya C. B., Korschun, D., \& Sen, S. (2011, December). What really drives value in corporate responsibility? Retrieved from

https://www.mckinseyquarterly.com/Strategy/Strategic_Thinking/What_really_drives_value_in_corporate_ responsibility_2895

5. Bhattacharya, C. B. (2009, November 20). Corporate social responsibility: It's all about marketing. Retrieved from http://www.forbes.com/2009/11/20/corporate-social-responsibility-leadership-citizenshipmarketing.html

6. Bonini, S. T. (2009, July). Valuing social responsibility programs. Retrieved from https://www.mckinseyquarterly.com/Marketing/Strategy/Valuing_social_responsibility_programs_2393

7. Colan, Kathleen. (2011, July 21). Opportunity calls: How to effectively capture mobile marketing conversions. Retrieved from http://www.marketingprofs.com/articles/2011/5499/opportunity-calls-how-toeffectively-capture-mobile-marketing-conversions\#ixzz1SycyiCDU

8. $\quad$ CVS Corporate Social Responsibility Report. (2013, May)

9. Dolliver, M. (2011, April 05). CMO.com. Retrieved from http://www.cmo.com/branding/positive-effectscause-related-marketing

10. Hall, L. (2010, July 6). Tying together social media and corporate social responsibility. Retrieved from http://www.convinceandconvert.com/pr-20/tying-together-social-media-and-corporate-socialresponsibility/

11. MarketingProfs. (2011, July 15). Use social serendipity to boost innovation. Retrieved from http://www.marketingprofs.com/short-articles/2339/use-social-serendipity-to-boost-innovation

12. Moorman, C. (2013, March 17). Do marketers know what they want from social media?" Retrieved from http://cmosurvey.org/blog/do-marketers-know-what-they-want-from-social-media/

13. NBC News. (2013, July 27). Bob Sullivan. \#MissingThePoint: Companies alienate customers with Twitter bots. Retrieved from http://www.nbcnews.com/technology/missingthepoint-companies-alienate-customerstwitter-bots-scripted-responses-6C10760870

14. Pearce, J. A. (2011). Strategic management. (12th ed.). New York, NY: McGraw Hill.

15. Skill Path Seminars. (2011, September). The social media marketing conference.

16. Stanchak, J. (2010, July 25). How whole foods market uses social media to keep its marketing fresh. Retrieved from http://smartblogs.com/socialmedia/2011/07/25/how-whole-foods-markets-uses-socialmedia-to-keep-its-marketing-fresh/

17. The Corporate Social Responsibility Newswire. Retrieved from http://www.csrwire.com/blog/posts/872social-where-csr-brand-leadership-is-won-or-lost

18. Zalk, G. (2013, June 28). Create a link between online and offline consumer behavior. Info@mail.dmnews.com

19. Zax, D. (2010, October 18). Fast Company. Retrieved from http://www.fastcompany.com/1695892/chevrons-new-ad-campaign-makes-lemonade

20. Zeisser, M. (2010, June). Unlocking the elusive potential of social networks. Retrieved from https://www.mckinseyquarterly.com/Unlocking_the_elusive_potential_of_social_networks_2623 


\section{NOTES}

